STUDIA PRAWNO-EKONOMICZNE, t. CV, 2017

PL ISSN 0081-6841; e-ISSN 2450-8179 s. 193-213

DOI: 10.26485/SPE/2017/105/12

Waldemar FLORCZAK*

Wojciech GRABOWSKI**

\title{
WYSTAPPIENIE PROBLEMU PRAWNEGO JAKO FUNKCJA CZYNNIKÓW INDYWIDUALNYCH I KONTEKSTOWYCH. ANALIZA EKONOMETRYCZNA Z WYKORZYSTANIEM HIERARCHICZNEGO MODELU LOGITOWEGO' ${ }^{1}$
}

\begin{abstract}
(Streszczenie)
Celem artykułu jest kwantyfikacja wpływu uwarunkowań mikroekonomicznych i mezoekonomicznych na indywidualne prawdopodobieństwo wystąpienia problemu prawnego. Na podstawie przeglądu literatury zidentyfikowano indywidualne czynniki ryzyka, zaś w oparciu o bazy danych regionalnych dla polskich powiatów ustalono listę regresorów mezoekonomicznych. Łącząc informacje dotyczące cech socjoekonomicznych respondentów z danymi regionalnymi, oszacowano parametry strukturalne hierarchicznego modelu logitowego. Zbiór regresorów objął czynniki mikro, zarówno obiektywne, jak i subiektywne - takie jak dochód, wiek, wykształcenie, stan cywilny, miejsce zamieszkania, postawę wobec prawa, świadomość prawną, kapitał ludzki czy aktywność społeczną - oraz czynniki mezo: uwarunkowania demograficzne i ekonomiczne. $Z$ badania przeprowadzonego na reprezentatywnej próbie dorosłych Polaków wynika, że czynniki ryzyka wystąpienia problemu prawnego zależą głównie od indywidualnych cech socjoekonomicznych respondentów, zaś uwarunkowania kontekstowe mają znacznie drugorzędne.
\end{abstract}

Słowa kluczowe: hierarchiczny model logitowy; problem prawny; uwarunkowania socjoekonomiczne; uwarunkowania kontekstowe

Klasyfikacja JEL: C25, K10

* Dr hab., prof. UJ, Uniwersytet Jagielloński, Wydział Zarządzania i Komunikacji Społecznej, Instytut Ekonomii, Finansów i Zarządzania, Zakład Analiz Społeczno-Ekonomicznych; e-mail: waldemar.florczak@uj.edu.pl

** Dr, Uniwersytet Łódzki, Wydział Ekonomiczno-Socjologiczny, Instytut Ekonometrii, Katedra Modeli i Prognoz Ekonometrycznych; e-mail: emfwog@uni.lodz.pl

1 Opracowanie powstało w ramach realizacji grantu NCN nr 2012/07/B/HS4/02994. 


\section{Wprowadzenie}

Wystapienie problemu prawego stanowi jeden z niezliczonych przejawów funkcjonowania jednostki w społeczeństwie $\mathrm{i}$ - tak jak inne wymiary życia - w dużym stopniu zależy od jej cech osobniczych i otoczenia społecznego. Pomimo oczywistości tego spostrzeżenia większość z istniejących procedur statystyczno-ekonometrycznych ma charakter dualny: albo służy celom analizy mikro, albo makro. W każdym z takich przypadków pojawią się natomiast ograniczenia dotyczące zakresu wnioskowania statystycznego, które określane są odpowiednio mianem błędu redukcjonizmu (reductionism fallacy) lub błędu ekologicznego (ecological fallacy). Jednym z nielicznych narzędzi ilościowych, które umożliwiają w ramach wspólnej analizy przezwyciężenie tych ograniczeń i jednoczesną kwantyfikację wpływu uwarunkowań mikro i makro na określone zjawiska/zachowania społeczne, są metody modelowania hierarchicznego (hierachical models).

Celem artykułu jest kwantyfikacja wpływu uwarunkowań mikroekonomicznych i mezoekonomicznych na indywidualne prawdopodobieństwo wystąpienia problemu prawnego. Aby lepiej zrozumieć ideę badania przeprowadzonego w niniejszym artykule, należy przytoczyć definicję pojęcia „problem prawny”. Respondenci byli pytani, czy w okresie ostatnich 5 lat znaleźli się w sytuacji wymagającej pomocy prawnika, osoby z wykształceniem prawniczym lub instytucji/ organizacji udzielającej porad prawnych. Na podstawie odpowiedzi respondentów definiowana była zmienna zależna przyjmująca wartość 1 dla tych respondentów, którzy odpowiedzieli „Tak” na zadane pytanie, oraz 0, jeśli odpowiedzieli „Nie” 2 .

Na podstawie przeglądu literatury zidentyfikowano indywidualne czynniki ryzyka, zaś w oparciu o bazy danych regionalnych dla polskich powiatów ustalono listę regresorów mezoekonomicznych. Łącząc informacje dotyczące cech socjoekonomicznych respondentów z danymi regionalnymi, oszacowano parametry strukturalne hierarchicznego modelu logitowego. Zbiór regresorów objął czynniki mikro - zarówno obiektywne, jak i subiektywne - takie jak dochód, wiek, wykształcenie, stan cywilny, miejsce zamieszkania, postawę wobec prawa, świadomość prawną, kapitał ludzki czy aktywność społeczną - oraz czynniki mezo: uwarunkowania demograficzne i ekonomiczne. $Z$ badania przeprowadzonego na reprezentatywnej próbie dorosłych Polaków wynika, że czynniki ryzyka wystapienia problemu prawnego zależą głównie od indywidualnych cech socjoekonomicznych respondentów, zaś uwarunkowania kontekstowe mają znacznie drugorzędne.

2 S. Burdziej, M. Dudkiewicz, Korzystajacy i niekorzystający z poradnictwa prawnego i obywatelskiego, Instytut Spraw Publicznych, Warszawa 2013. 
Struktura pracy jest następująca. W kolejnym punkcie omówiono kwestie metodyczne. Sekcja 3. zawiera dyskusję nad specyfikacją hierarchicznego modelu logitowego w nawiązaniu do ustaleń teoretycznych i wyników wcześniejszych, w tym autorskich, badań empirycznych. W punkcie 4. przytoczono rezultaty oryginalnych analiz i dokonano ich interpretacji. Artykuł zamykają uwagi końcowe.

\section{Hierarchiczny model logitowy - zarys metodyczny}

W niniejszym artykule rozważane jest badanie empiryczne mające na celu wyjaśnienie, jakie czynniki wpływają na fakt pojawienia się problemu prawnego. Dlatego też przedmiotem zainteresowania jest zmienna, która przyjmuje tylko dwie wartości. W związku z tym warto krótko omówić model dwumianowy. Model ten przyjmuje następującą postać:

$$
\begin{gathered}
y_{i}^{*}=\alpha_{0}+\alpha_{1} x_{1 i}+\ldots+\alpha_{K} x_{K i}+\varepsilon_{i}, \quad i=1, \ldots, N, \quad \varepsilon_{i} \sim F, \\
y_{i}=I\left\{y_{i}^{*}>0\right\},
\end{gathered}
$$

gdzie $I\{\cdot\}$ jest zmienną wskaźnikową, która przyjmuje wartość 1 , gdy spełniony jest warunek zdefiniowany w „klamrowym nawiasie” oraz $0 \mathrm{w}$ przeciwnym przypadku. $x_{1 i}, \ldots, x_{K i}$ są zmiennymi objaśniającymi.

W modelach dwumianowych najczęściej rozważane są 3 rozkłady składnika losowego. W zależności od wyboru rozkładu mamy do czynienia z modelem logitowym, probitowym lub komplementarnym modelem log-log. Wzory dla dystrybuant poszczególnych rozkładów zawarte są w tabeli 1 .

TABELA 1: Rozkłady składnika losowego dla różnych modeli dwumianowych

\begin{tabular}{|l|l|}
\hline \multicolumn{1}{|c|}{ Model } & \multicolumn{1}{|c|}{ Prawdopodobieństwo } \\
\hline Logitowy & $F\left(\alpha_{0}+\alpha_{1} x_{1 i}+\ldots+\alpha_{K} x_{K i}\right)=\frac{\exp \left(\alpha_{0}+\alpha_{1} x_{1 i}+\ldots+\alpha_{K} x_{K i}\right)}{1+\exp \left(\alpha_{0}+\alpha_{1} x_{1 i}+\ldots+\alpha_{K} x_{K i}\right)}$ \\
\hline Probitowy & $F\left(\alpha_{0}+\alpha_{1} x_{1 i}+\ldots+\alpha_{K} x_{K i}\right)=\int_{-\infty}^{\alpha_{0}+\alpha_{1} x_{i i}+\ldots+\alpha_{K} x_{K i}}(2 \pi)^{-1} \exp \left(-\frac{t^{2}}{2}\right) d t$ \\
\hline $\begin{array}{l}\text { Komplemen- } \\
\text { tarny log-log }\end{array}$ & $F\left(\alpha_{0}+\alpha_{1} x_{1 i}+\ldots+\alpha_{K} x_{K i}\right)=1-\exp \left[-\exp \left(\alpha_{0}+\alpha_{1} x_{1 i}+\ldots+\alpha_{K} x_{K i}\right)\right]$ \\
\hline
\end{tabular}

Ź r ó d ł o: C. Cameron, P. Triviedi, Microeconometrics Using Stata, Stata Press, College Station, Texas 2009; M. Gruszczyński, Mikroekonometria. Modele i metody analizy danych indywidualnych, Oficyna Wolters Kluwer business, Warszawa 2010. 
Parametry modelu dwumianowego najczęściej szacowane są metodą największej wiarygodności. Jeśli założenia dotyczące rozkładu składnika losowego są prawidłowe, estymator MNW istnieje i jest zgodny.

W naukach społecznych często mamy do czynienia z hierarchicznie ustrukturyzowanymi danymi. Różne czynniki oddziałują na wartości tzw. zmiennej wynikowej. Celem badacza jest określenie wpływu poszczególnych czynników na wartości wynikowe. Ideą modelowania hierarchicznego jest jednoczesna analiza powiązań międzygrupowych i wewnątrzgrupowych. W badaniach ekonomicznych często analizowane są powiązania w oparciu o dane zagregowane (np. dla powiatów, województw, państw). Jeśli jednak dysponujemy danymi indywidualnymi dla firm, gospodarstw domowych, respondentów w badaniu ankietowym, możliwa jest analiza powiązań w oparciu o dane indywidualne (zdezagregowane). Modelowanie hierarchiczne jest rozwiązaniem umożliwiającym połączenie wnioskowania na poziomie mikro i makro.

W rozważanym w niniejszym artykule badaniu empirycznym obserwowane są indywidualne jednostki oraz ich cechy socjoekonomiczne, które mogą mieć wpływ na fakt pojawienia się problemu prawnego u respondenta. Niemniej jednak w przypadku każdego respondenta dostępna jest także informacja dotycząca zamieszkiwanego przez niego powiatu. Dlatego też możliwe jest jednoczesne wykorzystanie informacji dotyczących wpływu zmiennych obserwowanych zarówno na poziomie indywidualnym, jak i zagregowanym (dla powiatów).

Zmienna zależna wykorzystywana $\mathrm{w}$ badaniu empirycznym przyjmuje tylko 2 wartości $(1-\mathrm{w}$ przypadku pojawienia się problemu prawnego oraz $0 \mathrm{w}$ przeciwnym przypadku). Dlatego też w celu identyfikacji wpływu zarówno cech indywidualnych, jak i kontekstowych (związanych ze środowiskiem zamieszkania respondenta) na prawdopodobieństwo zaistnienia problemu prawnego, należy szacować parametry następującego wielopoziomowego modelu logitowego:

$$
\mathbf{Y}=\mathbf{X} \boldsymbol{\beta}+\Delta \mathbf{Z} \boldsymbol{\gamma}+\Delta \boldsymbol{\mu}+\boldsymbol{\varepsilon},
$$

$\boldsymbol{\varepsilon} \sim N\left(\mathbf{0}, \mathbf{I}_{N} \sigma_{\varepsilon}^{2}\right)$,

$\boldsymbol{\mu} \sim N\left(\mathbf{0}, \mathbf{I}_{J} \sigma_{\mu}^{2}\right)$,

gdzie:

Y-wektor wartości dla zmiennej wynikowej o wymiarach $N \times 1$. i-ty element tego wektora definiowany jest następująco: $\frac{\operatorname{Pr}\left(Y_{i}=1\right)}{1+\operatorname{Pr}\left(Y_{i}=1\right)}$ 
$\mathbf{X}$ - macierz o wymiarach $N \times K$ zawierająca wektor ,jedynek" w pierwszej kolumnie oraz wektor obserwacji na zmiennych objaśniających w następnych kolumnach;

$\boldsymbol{\beta}$ - wektor parametrów do oszacowania o wymiarach $K \times 1$;

$\mathbf{Z}$ - macierz wartości dla zmiennych kontekstowych o wymiarach $J \times M$, gdzie $J$ oznacza liczbę grup kontekstowych, natomiast $M$ jest liczbą zmiennych kontekstowych;

$\boldsymbol{\gamma}$ - wektor parametrów o wymiarach $M \times 1$ ilustrujący wpływ zmiennych kontekstowych na zmienną zależną;

$\boldsymbol{\mu}$ - wektor losowych efektów grupowych o wymiarach $J \times 1$;

$\Delta$ - macierz o wymiarach $N \times J$ wskazująca na przynależność jednostek do grup:

$$
\boldsymbol{\Delta}=\left[\begin{array}{cccc}
\mathbf{n}_{1} & \mathbf{0} & \mathbf{0} & \mathbf{0} \\
\mathbf{0} & \ddots & \mathbf{0} & \mathbf{0} \\
\mathbf{0} & \mathbf{0} & \ddots & \mathbf{0} \\
\mathbf{0} & \mathbf{0} & \mathbf{0} & \mathbf{n}_{J}
\end{array}\right],
$$

gdzie $\mathrm{n}_{1}, K \mathrm{n}_{\mathrm{J}}$ są kolumnowymi wektorami ,jedynek" o długościach odpowiadających liczbie obserwacji tworzących kolejne grupy.

O ile estymacja parametrów modelu wielopoziomowego metodą największej wiarygodności nie jest skomplikowanym zadaniem w przypadku ciąłych zmiennych zależnych ${ }^{3}$, o tyle przypadek dyskretnej (np. dychotomicznej) zmiennej zależnej zmusza do zastosowania bardziej skomplikowanych metod. Wynika to $\mathrm{z}$ faktu, że w przypadku dyskretnego rozkładu zmiennej wynikowej wartość funkcji wiarygodności obliczana jest poprzez całkowanie iloczynu gęstości zmiennej ciągłej i rozkładu prawdopodobieństwa zmiennej dyskretnej. A zatem analityczne rozwiązanie nie istnieje.

W celu rozwiązania tego problemu zostały stworzone dwa rodzaje aproksymacji: krańcowej quasi-wiarygodności oraz karnej quasi-wiarygodności ${ }^{4}$. Polegają one na zamianie dyskretnej hierarchicznej wiarygodności poprzez gaussowską

3 H. Goldstein, Multilevel mixed linear model analysis using iterative generalised least squares, Biometrika 1986/73; H. Goldstein, Restricted unbiased iterative generalised least squares estimation, Biometrika 1989/76.

4 N. Breslow, D.G. Clayton, Approximate inference in generalised linear mixed models, Journal of the American Statistical Association 1993/88; H. Goldstein, J. Rasbash, Improved approximations for multilevel models with binary responses, Journal of the Royal Statistical Society, Series A 1996/159. 
hierarchiczną wiarygodność. Niemniej jednak zastosowanie tych aproksymacji prowadzi do obciążonych (w kierunku „zera”) estymatorów ${ }^{5}$.

Ze względu na wskazane obciążenie zaproponowane zostały metody jego korekty. Lin i Breslow ${ }^{6}$ zaproponowali korektę obciążenia metodą analityczną, natomiast Raudenbusch i in. ${ }^{7}$ zaproponowali rozwinięcie w szereg Taylora wyższego rzędu funkcji karnej quasi-wiarygodności. Bootstrapowa metoda korekty obciążenia została zaproponowana przez Kuka ${ }^{8}$. Zastosowanie powyższych metod rozwiązuje problem obciążenia estymatorów, jednak pojawiają się problemy związane z oszacowaniem średnich błędów szacunku dla estymatorów oraz maksymalnej wartości funkcji wiarygodności. Najpopularniejszą metodą estymacji parametrów hierarchicznych modeli logitowych jest symulacyjna metoda największej wiarygodności ${ }^{9}$. Dzięki jej zastosowaniu uzyskuje się nieobciążone estymatory parametrów oraz nieobciążony estymator wariancji-kowariancji estymatorów. Nie ma też problemu z uzyskaniem wartości maksymalnej funkcji wiarygodności. Symulacyjna metoda największej wiarygodności wykorzystywana jest podczas estymacji parametrów hierarchicznego modelu logitowego zaproponowanego w niniejszym artykule.

W celu sprawdzenia, czy hierarchiczny model logitowy jest lepszy od klasycznego, wykorzystywany jest test ilorazu wiarygodności. Jako alternatywny wobec modelu (1) rozważa się ,klasyczny” model logitowy, w którym zmienne wchodzące w skład macierzy $\mathbf{Z}$ dołączane są do macierzy $\mathbf{X}$, natomiast element $\Delta \boldsymbol{\mu}$ nie jest uwzględniany. W związku z tym wykorzystywana jest statystyka:

$$
L R=2\left(\ln L_{\text {hier }}-\ln L_{\text {klas }}\right),
$$

gdzie $\ln L_{\text {hier }}$ oraz $\ln L_{\text {klas }}$ oznaczają odpowiednio logarytm z funkcji wiarygodno-

5 G. Rodríguez, N. Goldman, An assessment of estimation procedures for multilevel models with binary responses, Journal of the Royal Statistical Society, Series A 1995/158; X. Lin Xihong, N. Breslow, Bias correction in generalised linear mixed models with multiple components of dispersion, Journal of the American Statistical Association 1996/91.

6 X. Lin Xihong, N. Breslow, Bias correction in generalised linear mixed models with multiple components of dispersion, Journal of the American Statistical Association 1996/91.

7 S. Raudenbush, Yang Meng-Li, M. Yosef, Maximum likelihood for generalized linear models with nested random effects via high-order, multivariate Laplace approximation, Journal of Computational and Graphical Statistics 2000/9.

8 A. Kuk, Asymptotically unbiased estimation in generalised linear models with random effects, Journal of the Royal Statistical Society, Series B 1995/57.

9 Ch. McCulloch, Maximum likelihood algorithms for generalised linear mixed models, Journal of the American Statistical Association 1997/92; E. Ng, J. Carpenter, H. Goldstein, J. Rasbash, Estimation in generalised linear mixed models with binary outcomes by simulated maximum likelihood, Statistical Modelling 2006/6. 
ści odpowiednio dla hierarchicznego oraz klasycznego modelu logitowego. Przy prawdziwości hipotezy zerowej, statystyka (2) ma rozkład chi-kwadrat z jednym stopniem swobody. Brak podstaw do odrzucenia hipotezy zerowej wskazuje, że zastosowanie hierarchicznego modelu logitowego nie jest uzasadnione, a „klasyczny" model logitowy jest lepszym rozwiązaniem.

\section{Dane i specyfikacja modelu}

Analizy empiryczne przeprowadzono przy wykorzystaniu danych uzyskanych w ogólnopolskiej, reprezentatywnej ankiecie przez Instytut Spraw Publicznych w Warszawie w 2012 r. Cytowane „badanie zostało przeprowadzone na podstawie przygotowanej przez ekspertów ISP koncepcji badawczej, określającej główne kwestie badawcze, metody oraz zakres podmiotowy badania. Analizy opierały się na triangulacji źródeł informacji, czyli rozpatrywaniu problemów badawczych z trzech różnych perspektyw: świadczeniodawców usług poradniczych, potencjalnych i rzeczywistych świadczeniobiorców oraz instytucjonalnego otoczenia poradnictwa [...]. W badaniu zastosowano zarówno metody ilościowe, jak i jakościowe [...]. W części dotyczącej usługodawców przeprowadzono 450 wywiadów telefonicznych, 100 ankiet internetowych, 40 indywidualnych wywiadów pogłębionych, 10 studiów przypadku oraz 2 zogniskowane wywiady grupowe. Badanie objęło przedstawicieli kilkunastu różnych typów usługodawców publicznych i niepublicznych oraz ekspertów (wywiady grupowe)"10.

$\mathrm{W}$ przypadku badania beneficjentów „,W ramach badań reprezentatywnych zrealizowano 1050 wywiadów bezpośrednich (PAPI) na próbie ogólnopolskiej [...]. Próba badawcza musiała spełniać kryterium reprezentatywności dla populacji polskiej w wieku 18 i więcej lat, z kolei dobór musiał być losowy, aby wyniki można było ekstrapolować na całą populację [...]. W badaniu zastosowano próbę losowo-warstwową, dzięki której uzyskano strukturę identyczną ze strukturą populacji ze względu na wiek, płeć, wielkość miejscowości zamieszkania i województwo, a sam dobór respondentów na terenie był realizowany zgodnie $\mathrm{z}$ formułą random route" 11 .

10 A. Preisert, T. Schimanek, M. Waszak, A. Winiarska, Poradnictwo prawne i obywatelskie w Polsce. Stan obecny $i$ wizje przyszłości, Instytut Spraw Publicznych, Warszawa 2013, s. 14 (szeroko na ten temat - tamże).

11 S. Burdziej, M. Dudkiewicz, Korzystajacy i niekorzystający z poradnictwa prawnego i obywatelskiego, Instytut Spraw Publicznych, Warszawa 2013, s. 4 (szeroko na ten temat - tamże). 
Bazę danych zawierającą podstawowe dane demograficzne i ekonomiczne na poziomie powiatowym uzyskano dzięki uprzejmości prof. dr. hab. Tomasza Tokarskiego z Uniwersytetu Jagiellońskiego. Zawiera ona szeregi czasowe za lata 2002-2013, zaś dla potrzeb analitycznych niniejszego badania uwzględniono następujące informacje: PKB per capita, liczbę mieszkańców przypadających na jeden podmiot gospodarczy, udział osób pracujących w populacji ogółem, płacę przeciętną oraz stopę bezrobocia. Łatwo zauważyć, że powyższe zmienne obejmująjedynie regionalny kontekst ekonomiczny. Jednakże twarde dane dotyczące innych uwarunkowań kontekstowych pomocy prawnej nie są na szczeblu powiatowym dostępne.

Przegląd literatury teoretycznej i empirycznej ${ }^{12}$ wskazuje na następujące grupy czynników ryzyka wystapienia problemu prawnego:

a) indywidualne cechy społeczno-ekonomiczne i demograficzne,

b) indywidualne postawy wobec przestrzegania i stosowania prawa,

c) indywidualna aktywność społeczna,

d) środowisko społeczno-ekonomiczne i bariery dostępu do poradnictwa prawnego.

Pytania kwestionariuszowe, zawarte w ogólnopolskiej ankiecie Instytutu Spraw Publicznych w Warszawie, objęły wszystkie wyżej wymienione uwarunkowania, co dało możliwość konstrukcji modelu logitowego objaśniającego prawdopodobieństwo wystąpienia problemu prawnego. Wyniki kompleksowego metodycznie badania Florczaka i Grabowskiego ${ }^{13}$ wskazały, że czynniki, które

12 M. Murayama, Experiences of Problems and Disputing Behaviour in Japan, Meiji Law Journal 2007/14; H. Kritzer, To Lawer or Not to Lawyer: Is that the Question?, Journal of Empirical Legal Studies 2008/5; P. Pleasence, N. Balmer, S. Reimers, What Really Drives Advice Seeking Behaviour? Looking Beyond the Subject of Legal Disputes, Onati Socio-Legal Series 2011/1; J. Winczorek, Przeglad literatury na temat dostępności i korzystania z pomocy prawnej, INPRIS 2015.

13 W. Florczak, W. Grabowski, Co wpływa na wielkość popytu na porady prawne? Analiza logitowa z wykorzystaniem metody klasycznego uśredniania międzymodelowego, Przegląd Statystyczny 2017, przyjęto do druku. W cytowanym badaniu zastosowano sekwencję kilku metod/procedur ekonometrycznych. W kroku pierwszym dokonano specyfikacji i oszacowano parametry zdezagregowanego - tj. uwzględniającego szereg szczegółowych odpowiedzi na pytania ankietowe - dwumianowego modelu logitowego, obejmującego ponad 50 regresorów. Z powodu zbyt dużego stopnia dezagregacji uzyskane rezultaty okazały się niezgodne z przesłankami logicznymi i teoretycznymi. Zastosowanie wariantu specyfikacji zagregowanej, w którym liczba regresorów wyniosła 26, doprowadziło do wyników zgodnych z ustaleniami merytorycznymi, jednakże znaczna część zmiennych objaśniających okazała się statystycznie nieistotna. Dlatego w kolejnym kroku zastosowano strategię modelowania od ogółu do szczegółu, w efekcie czego otrzymano wariant, w którym wszystkie regresory okazały się statystycznie 
w statystycznie istotny sposób oddziałują na prawdopodobieństwo wystapienia problemu prawnego, reprezentują wszystkie wyszczególnione grupy ryzyka. Jednakże cytowane badanie nie uwzględniło uwarunkowań kontekstowych, który to brak wypełnia niniejsze opracowanie.

W tabeli 2 przedstawiono listę czynników ryzyka wystąpienia problemu prawnego - wraz ze zwięzłym uzasadnieniem teoretycznym i odwołaniem do wcześniejszych analiz empirycznych - które uznano za statystycznie istotne na $20 \%$ poziomie istotności ${ }^{14} \mathrm{~W}$ badaniu Florczaka i Grabowskiego ${ }^{15}$. Na podstawie przesłanek logicznych i dotychczasowych ustaleń teoretycznych każdemu regresorowi przypisano oczekiwany tam znak parametru (,,+” lub ,--"). Dla większości zmiennych $\mathrm{w}$ tabeli 2 znaki te nie są jednak z góry ustalone, którą to sytuację oznaczono symbolem (?). Należy przy tym zaznaczyć, że zarówno znaki parametrów, jak i ich interpretacja jest warunkowa zarówno względem sposobu kodowania danej zmiennej objaśniającej ${ }^{16}$, jak i kategorii referencyjnej w hierarchicznym modelu logitowym ${ }^{17}$.

Większość z tych zmiennych przedstawiona jest w postaci zmiennych 0-1, co - po podaniu w odpowiednich kolumnach tabeli 2 informacji o kategorii referencyjnej (opcja, dla której dana zmienna przyjmuje wartość „0”) - umożliwia zrozumienie ich konstrukcji oraz oczekiwanego znaku parametru (tam, gdzie takie ustalenia $\mathrm{w}$ odniesieniu do kierunku zależności pomiędzy regresorem a regresantem były a priori możliwe). Pewne zmienne z omawianych grup regresorów mają charakter polichotomiczny (stan cywilny, wykształcenie), kilka zmiennych objaśniających przyjmuje wartości z przedziałów całkowitoliczbowych (wiek, postawa wobec stosowania prawa), zaś jedna zmienna objaśniająca - dochód na osobę w gospodarstwie - wyrażona jest w jednostkach pieniężnych (w zł na osobę).

istotne. I wreszcie w celu zbadania odporności otrzymanych rezultatów, zastosowano metodę częstościowego uśredniania międzymodelowego.

14 Przyjęcie tak wysokiego poziomu istotności wynikało z eksploracyjnego charakteru cytowanego badania.

15 W. Florczak, W. Grabowski, op. cit.

16 Np. w przypadku zmiennej dychotomicznej takiej jak „płeć” wartość „0” przypisano do mężczyzn, zaś wartość „1” do kobiet, dlatego oczekiwany znak parametru stojącego przy tej zmiennej jest dodatni (kobiety częściej doświadczają problemów prawnych). Oczywiście jednoczesna zmiana sposobu kodowania (,0” - kobiety, „1” - mężczyźni) skutkowałaby apriorycznym wskazaniem ujemnej ceteris paribus zależności pomiędzy taką zmienną a regresantem.

17 Zmienną referencyjną w modelu jest brak problemu prawnego. 
Odrębnego komentarza wymaga grupa czynników dotycząca indywidualnych postaw prawnych. Postawy wobec przestrzegania i stosowania prawa są cechami osobniczymi, które - w świetle literatury tematu ${ }^{18}$ - mogą wpływać na umiejętność poprawnej identyfikacji problemu życiowego jako problemu prawnego, i tym samym oddziaływać na podatność na występowanie problemów prawnych. W badaniu niniejszym pierwszy $\mathrm{z}$ wymienionych obszarów jest reprezentowany wyrażanymi przez respondenta poglądami na temat przestrzegania prawa $\mathrm{w}$ postaci jednej z czterech odpowiedzi na następujące pytanie: Na temat praktycznego przestrzegania prawa w życiu są różne poglady. Prosimy wybrać z przytoczonych zdań to, które bardziej P. odpowiada:

1. Powinno się zawsze przestrzegać prawa, nawet jeśli jest ono niestuszne;

2. Jeśli napotyka się przepisy prawa naszym zdaniem niestuszne, należy się do nich stosować tylko na pozór, a praktycznie starać się je omijać;

3. Do przepisów, które uważamy za niestuszne, nie należy się wogóle stosować;

4. (nie czytać) nie wiem / trudno powiedzieć,

przy czym zmienna objaśniana przyjmuje wartość „1” dla odpowiedzi pierwszej, zaś wartość „0” dla pozostałych opcji (zmienna PCPL w tabeli 2).

W odniesieniu do poglądów dotyczących stosowania prawa wymiar ten reprezentowany jest zmienną polichotomiczną PUSE przyjmującą wartości całkowite $z$ przedziału $<0,3>$. Odpowiednia zmienna objaśniająca powstaje w wyniku zsumowania afirmatywnych odpowiedzi nr 1 na pytanie ankietowe, cyt. $W$ sytuacji konfliktu, sporu z innymi, ludzie często podejmuja różne działania. Co P. zdaniem jest lepsze w takiej sytuacji? Możliwe odpowiedzi objęły trzy opcje i trzy zbiory wariacji $\mathrm{w}$ temacie postaw względem stosowania prawa:

1. Zaspokojenie w petni żądań jednej ze stron, choćby druga byta z tego niezadowolona,

2. Doprowadzenie do obopólnej zgody na zasadzie, że każdy rezygnuje po trosze ze swych roszczeń,

3. (nie czytać) nie wiem / trudno powiedzieć.

1. Rozstrzygnięcie sporu ściśle wedtug przepisów prawa, choćby druga strona była z tego niezadowolona,

18 H. Kritzer, B. Bogart, N. Vidmar, Context, Context, Context: A Cross-problem, Cross-Cultural Comparison of Compensation Seeking Behaviour, Paper Prepared for Law and Society, Amsterdam 1991; J. Kurczewski, M. Fuszara, Polskie spory i sądy, Ośrodek Badań Społecznych ISNS, Uniwersytet Warszawski, Warszawa 2004. 
2. Rozstrzygnięcie sporu ku zadowoleniu obu stron, choćby nie było to ściśle wedtug przepisu prawa,

3. (nie czytać) nie wiem / trudno powiedzieć.

1. Rozwiązanie sporu przez instytucję, np. sąd, która ma władzę i może narzucić swoje rozwiazanie,

2. Rozwiazanie sporu przez postronnych ludzi, którzy moga jedynie doradzić zwaśnionym stronom, jak postępować,

3. (nie czytać) nie wiem / trudno powiedzieć.

Im bardziej przy tym pryncypialna i roszczeniowa postawa wobec stosowania prawa ze strony danej osoby, a zatem im wyższa wartość zmiennej PUSE, tym wyższe jest prawdopodobieństwo zaistnienia problemu prawnego.

TABELA 2: Lista zmiennych indywidualnych cech socjoekonomicznych respondentów

\begin{tabular}{|c|c|c|c|c|c|}
\hline Lp. & Czynniki & $\begin{array}{c}\text { Symbol } \\
\text { zmiennej } \\
\text { jednostka } \\
\text { miary }\end{array}$ & $\begin{array}{l}\text { Uzasadnienie teoretyczne z zakresu nauk } \\
\text { społecznych (socjologicznych, prawnych, } \\
\text { ekonomicznych) i aplikacje }\end{array}$ & $\begin{array}{l}\text { Ocze- } \\
\text { kiwany } \\
\text { znak para- } \\
\text { metru }\end{array}$ & $\begin{array}{l}\text { Uwagi } \\
\text { oraz katego- } \\
\text { ria referen- } \\
\text { cyjna }\end{array}$ \\
\hline \multicolumn{6}{|c|}{ Cechy społeczno-demograficzne } \\
\hline 1. & Płeć & $\begin{array}{l}\text { FEM } \\
(0-1)\end{array}$ & $\begin{array}{c}\text { W świetle ustaleń empirycznych kobiety } \\
\text { przyjmują bardziej aktywną postawę wobec } \\
\text { zaistniałych problemów prawnych: } \\
\text { Murayama (2007), } \\
\text { Hunter, De Simone (2009), } \\
\text { Preisert i in. (2013) }\end{array}$ & $(+)$ & $\begin{array}{l}\text { Kategoria } \\
\text { referencyjna: } \\
\text { mężczyzna }\end{array}$ \\
\hline 2. & Wiek & $A G E$ & \multirow[b]{2}{*}{$\begin{array}{l}\text { Występowanie problemów prawnych jest } \\
\text { zależne od wieku respondentów, przy czym } \\
\text { zależność ta nie ma charakteru liniowego: } \\
\text { prawdopodobieństwo wystąpienia pro- } \\
\text { blemu początkowo rośnie z wiekiem, zaś } \\
\text { po osiagnięciu punktu zwrotnego zaczyna } \\
\text { maleć. Wynika to z szeroko rozumianego } \\
\text { cyklu życia jednostki: Pleasence i in. (2004), } \\
\text { Currie (2006), Coumarelos i in. (2006), } \\
\text { Curran (2007) }\end{array}$} & $(+)$ & \multirow[b]{2}{*}{$\begin{array}{l}\text { Brak } \\
\text { kategorii } \\
\text { referencyjnej } \\
\text { (zmienna } \\
\text { ciagła) }\end{array}$} \\
\hline 3. & $\begin{array}{l}\text { Wiek do } \\
\text { kwadratu }\end{array}$ & $A G E^{2}$ & & $(-)$ & \\
\hline 4. & $\begin{array}{l}\text { Wykształce- } \\
\text { nie ponad- } \\
\text { podstawowe }\end{array}$ & $\begin{array}{c}E D U P \\
(0-1)\end{array}$ & \multirow{2}{*}{$\begin{array}{c}\text { Ceteris paribus lepsze wykształcenie powin- } \\
\text { no skutkować obszerniejszą wiedzą ogólną } \\
\text { i tym samym bardziej aktywną postawą } \\
\text { wobec zaistniałego problemu prawnego: } \\
\text { Legal Service Corporation (1994), } \\
\text { Murayama (2007), } \\
\text { Preisert i in. (2013) }\end{array}$} & \multirow[b]{2}{*}{$(+)$} & \multirow{2}{*}{$\begin{array}{l}\text { kategoria } \\
\text { referencyjna: } \\
\text { wykształ- } \\
\text { cenie } \\
\text { podstawowe } \\
\text { i niższe }\end{array}$} \\
\hline 5. & $\begin{array}{l}\text { Wykształce- } \\
\text { nie ponad- } \\
\text { średnie }\end{array}$ & $\begin{array}{c}E D U S \\
(0-1)\end{array}$ & & & \\
\hline
\end{tabular}




\begin{tabular}{|c|c|c|c|c|c|}
\hline Lp. & Czynniki & $\begin{array}{c}\text { Symbol } \\
\text { zmiennej / } \\
\text { jednostka } \\
\text { miary }\end{array}$ & $\begin{array}{l}\text { Uzasadnienie teoretyczne z zakresu nauk } \\
\text { społecznych (socjologicznych, prawnych, } \\
\text { ekonomicznych) i aplikacje }\end{array}$ & $\begin{array}{c}\text { Ocze- } \\
\text { kiwany } \\
\text { znak para- } \\
\text { metru }\end{array}$ & $\begin{array}{l}\text { Uwagi } \\
\text { oraz katego- } \\
\text { ria referen- } \\
\text { cyjna }\end{array}$ \\
\hline 6. & $\begin{array}{l}\text { Stan cywil- } \\
\text { ny (żonaty/ } \\
\text { mężatka) }\end{array}$ & $\begin{array}{c}S C Z O \\
(0-1)\end{array}$ & \multirow{3}{*}{$\begin{array}{l}\text { Stan cywilny w dużym stopniu wpływa na } \\
\text { inne cechy osobnicze, które mogą oddziały- } \\
\text { wać na percepcję rzeczywistości i warunkują } \\
\text { przyjmowanie określonych postaw i zacho- } \\
\text { wań w sytuacji wystapienia problemu: } \\
\text { Legal Service Corporation (1994), } \\
\text { Murayama (2007), } \\
\text { Preisert i in. (2013) }\end{array}$} & \multirow{3}{*}{ (?) } & \multirow{3}{*}{$\begin{array}{l}\text { Kategoria } \\
\text { referencyjna: } \\
\text { „kawaler/ } \\
\text { panna" }\end{array}$} \\
\hline 7. & $\begin{array}{l}\text { Stan cywil- } \\
\text { ny (rozwod- } \\
\text { nik/ } \\
\text { rozwódka) } \\
\end{array}$ & $\begin{array}{c}S C R O \\
(0-1)\end{array}$ & & & \\
\hline 8. & $\begin{array}{l}\text { Stan cywil- } \\
\text { ny (wdo- } \\
\text { wiec/ } \\
\text { wdówa) }\end{array}$ & $\begin{array}{c}S C W D \\
(0-1)\end{array}$ & & & \\
\hline \multicolumn{6}{|c|}{ Cechy ekonomiczno-społeczne } \\
\hline 9. & \begin{tabular}{|c|} 
Logarytm \\
dochodu na \\
osobę w go- \\
spodarstwie \\
\end{tabular} & $\begin{array}{c}\ln D O C H \\
\text { (zt) }\end{array}$ & \multirow{2}{*}{$\begin{array}{l}\text { Wyższy dochód zmniejsza bariery dostę- } \\
\text { pu do usług prawnych, zwłaszcza ko- } \\
\text { mercyjnych. Osoby z relatywnie niskim } \\
\text { i relatywnie wysokim dochodem częściej } \\
\text { doświadczają problemów prawnych, chociaż } \\
\text { z innych przyczyn: Legal Service Corpora- } \\
\text { tion (1994), Murayama (2007), Preisert i in. } \\
\text { (2013) }\end{array}$} & $(-)$ & \multirow{2}{*}{$\begin{array}{c}\text { Brak } \\
\text { kategorii } \\
\text { referencyjnej } \\
\begin{array}{c}\text { (zmienna } \\
\text { ciągła) }\end{array}\end{array}$} \\
\hline 10. & \begin{tabular}{|c|} 
Logarytm \\
dochodu na \\
osobę w go- \\
spodarstwie \\
do kwadratu \\
\end{tabular} & $\ln D O C H^{2}$ & & $(+)$ & \\
\hline 11. & $\begin{array}{l}\text { Miejsce za- } \\
\text { mieszkania }\end{array}$ & $\begin{array}{l}\text { RESD } \\
(0-1)\end{array}$ & $\begin{array}{c}\text { Mieszkańcy miast mają łatwiejszy dostęp } \\
\text { zarówno do niekomercyjnych, jak i komer- } \\
\text { cyjnych usług prawnych. Zatem miejsce } \\
\text { zamieszkania może stanowić barierę dostępu } \\
\text { do pomocy prawnej: } \\
\text { Murayama (2007), } \\
\text { Preisert i in. (2013) }\end{array}$ & $(+)$ & $\begin{array}{c}\text { Wieś } \\
\text { i miasteczko } \\
\text { (poniżej } 20 \\
\text { tys. miesz- } \\
\text { kańców) - } 0 \\
\text { Miasto - } 1\end{array}$ \\
\hline 12. & $\begin{array}{c}\text { Stan } \\
\text { zdrowia } \\
\text { własnego } \\
\text { lub członka } \\
\text { rodziny }\end{array}$ & $\begin{array}{l}H T H \\
(0-1)\end{array}$ & $\begin{array}{c}\text { Afirmatywy wybór przynajmniej jednej } \\
\text { z opcji odpowiedzi na następujące pytanie: } \\
\text { Czy w ciagu ostatnich dwunastu miesięcy: } \\
\text { cierpiat/a P. z powodu dlugotrwatej choroby, } \\
\text { cierpiat/a P. z powodu niepetnosprawności, } \\
\text { byt/a P. pacjentem/ka szpitala, } \\
\text { byt/a P. przez miesiac lub dtużej niezdolny- } \\
\text { /a do wykonywania swojej pracy zawodowej } \\
\text { lub codziennych obowiazków w zwiazku } \\
\text { z choroba lub obrażeniami ciała? } \\
\text { Curran (2007), Coumarelos i in. (2006) } \\
\text { W przypadku stanu zdrowia członka rodziny } \\
\text { analogiczny zestaw pytań }\end{array}$ & $(+)$ & $\begin{array}{l}\text { Zmienna } \\
\text { referencyjna: } \\
\text { odpowiedź } \\
\text { Nie }\end{array}$ \\
\hline
\end{tabular}




\begin{tabular}{|c|c|c|c|c|c|}
\hline Lp. & Czynniki & $\begin{array}{l}\text { Symbol } \\
\text { zmiennej / } \\
\text { jednostka } \\
\text { miary }\end{array}$ & $\begin{array}{l}\text { Uzasadnienie teoretyczne z zakresu nauk } \\
\text { społecznych (socjologicznych, prawnych, } \\
\text { ekonomicznych) i aplikacje }\end{array}$ & $\begin{array}{l}\text { Ocze- } \\
\text { kiwany } \\
\text { znak para- } \\
\text { metru }\end{array}$ & $\begin{array}{l}\text { Uwagi } \\
\text { oraz katego- } \\
\text { ria referen- } \\
\text { cyjna }\end{array}$ \\
\hline \multicolumn{6}{|c|}{ Postawa wobec przestrzegania i stosowania prawa oraz postawa społeczna } \\
\hline 13. & $\begin{array}{c}\text { Postawa } \\
\text { wobec prze- } \\
\text { strzegania } \\
\text { prawa }\end{array}$ & $\begin{array}{c}P C P L \\
(0-1)\end{array}$ & $\begin{array}{c}\text { Postawa wobec przestrzegania prawa rzu- } \\
\text { tuje na sposób rozwiązywania problemów } \\
\text { prawnych: Kritzer i in. (1991), Kurczewski, } \\
\text { Fuszara (2004), }\end{array}$ & $(+)$ & $\begin{array}{l}\text { Komentarz } \\
\text { w tekście } \\
\text { zasadniczym }\end{array}$ \\
\hline 14. & \begin{tabular}{|} 
Postawa \\
wobec \\
stosowania \\
prawa
\end{tabular} & $\begin{array}{l}\text { PUSE } \\
\text { (liczba } \\
\text { całkowita } \\
\text { z prze- } \\
\text { działu } \\
0-3 \text { ) }\end{array}$ & $\begin{array}{c}\text { Postawa wobec stosowania prawa jest ważka } \\
\text { i trwałą cechą osobniczą rzutującą na sposób } \\
\text { rozwiązywania problemów prawnych: } \\
\text { Kritzer i in. (1991), Kurczewski, Fuszara } \\
\text { (2004) }\end{array}$ & $(+)$ & $\begin{array}{l}\text { Postawa ugo- } \\
\text { dowa: } P U S E \\
=0 ; \text { postawa } \\
\text { roszczenio- } \\
\text { wa: } P U S E= \\
3 \text { (komentarz } \\
\text { w tekście za- } \\
\text { sadniczym) }\end{array}$ \\
\hline \multicolumn{6}{|c|}{ Aktywność społeczna } \\
\hline 15. & $\begin{array}{c}\text { Działalność } \\
\text { społeczna }\end{array}$ & $\begin{array}{c}A A C T \\
(0-1)\end{array}$ & $\begin{array}{c}\text { Aktywność społeczna świadczy o opera- } \\
\text { tywności, inicjatywności upodmiotowieniu } \\
\text { i uspołecznieniu osób aktywnych, co po- } \\
\text { winno skutkować innymi sposobami reakcji } \\
\text { na zaistnienie problemu prawnego niż osób } \\
\text { mniej społecznie aktywnych: } \\
\text { Murayama (2007), Preisert i in. (2013) }\end{array}$ & (?) & $\begin{array}{l}\text { Nie: } A A C T \\
\quad=0 \\
\text { Tak: } A A C T \\
\quad=1\end{array}$ \\
\hline 16. & $\begin{array}{c}\text { Korzystanie } \\
\text { z Internetu }\end{array}$ & $\begin{array}{l}\text { INTC } \\
(0-1)\end{array}$ & $\begin{array}{c}\text { Następująca odpowiedź na pytanie, cyt. Jak } \\
\text { często zagląda P. do serwisów i portali in- } \\
\text { ternetowych: „Raz w tygodniu lub częściej”: } \\
\text { Preisert i in. (2013) }\end{array}$ & (?) & $\begin{array}{l}\text { Kategoria } \\
\text { referencyjna: } \\
\text { inne odpo- } \\
\text { wiedzi }\end{array}$ \\
\hline
\end{tabular}

Źr ó dło: opracowanie własne.

Postać analityczna pozostałych zmiennych objaśniających wyszczególnionych w tabeli 2 jest - jak się wydaje - na tyle jednoznaczna, że zrezygnowano z ich dokładniejszego opisu w tekście zasadniczym. Omówić zatem pozostaje czynniki kontekstowe, które ze względu na dostępność danych ograniczają się do wymiaru ekonomicznego i obejmują następujące kategorie:

1) PKB per capita - średnia pięcioletnia dla okresu 2008-201219; symbol zmiennej: $P K B$;

19 W ogólnopolskim badaniu ankietowym ISP, przeprowadzonym w 2012 r., pytanie o doświadczenie problemu prawnego ze strony respondenta dotyczyło okresu 5-ciu minionych lat, co 
2) Liczba mieszkańców / Liczba REGON - średnia pięcioletnia dla okresu 2008-2012; symbol zmiennej: NREG;

3) (Pracujący / Liczba mieszkańców)*100 - średnia pięcioletnia dla okresu 2008-2012; symbol zmiennej: EN;

4) Płace przeciętne - średnia pięcioletnia dla okresu 2008-2012; symbol zmiennej: $W$;

5) Stopa bezrobocia - średnia pięcioletnia dla okresu 2008-2012; symbol zmiennej: $U N R$.

Dodatkowo, oprócz średnich poziomów wymienionych wyżej kategorii, zdecydowano się również na wprowadzenie ich średnich temp wzrostu za lata 2008-2012, korzystając z formuły $\left(\sqrt[4]{\frac{X_{2012}}{X_{2008}}}-1\right) \cdot 100 \%$, gdzie X oznacza poziomy zmiennych kontekstowych. Zmiennym tym przypisano symbole analogiczne do wcześniej wymienionych, ale z końcówką "_T" (np. PKB_T oznacza średnie pięcioletnie tempo wzrostu w latach 2008-2012).

Merytoryczną przesłanką takiego poszerzenia specyfikacji jest dość powszechnie w naukach społecznych formułowana hipoteza, że dynamika procesów może wpływać w sposób autonomiczny i niezależny od uwarunkowań zastanych (aproksymowanych poziomami zmiennych) na zmienność różnorodnych zjawisk społeczno-ekonomicznych ${ }^{20}$. Stwierdzić należy również, że wobec braku jednoznacznych ustaleń teoretycznych, jak i zaawansowanych metodycznie badań empirycznych w obszarze będącym przedmiotem dociekań niniejszego artykułu, proponowane w nim rozwiązania oraz uzyskane rezultaty oceniane powinny być poprzez pryzmat badań eksploracyjnych, nie zaś eksplanacyjnych. Dlatego zrezygnowano z próby apriorycznego wskazania oczekiwanych znaków parametrów stojących przy zmiennych kontekstowych.

Wyjściowe specyfikacje hierarchicznego modelu logitowego, objaśniającego prawdopodobieństwo wystąpienia problemu prawnego są następujące:

oznacza, że pomiar czynników kontekstowych dokonywany powinien być dla wartości średnich z lat 2008-2012.

20 R. Barro, Inequality and Growth in a Panel of Countries, Journal of Economic Growth 2000/5; J. Chang, R. Ram, Level of Development, Rate of Economic Growth, and Income Inequality, Economic Development and Cultural Change 2000/48. 
Dla wariantu 16 zmiennych z poziomu mikro:

$$
\begin{aligned}
& \ln \left(\frac{P_{i}}{1-P_{i}}\right)=\beta_{0}+\beta_{1} F E M_{i}+\beta_{2} A G E_{i}+\beta_{3} A G E 2_{i}+\beta_{4} E D U P_{i}+\beta_{5} E D U S_{i}+\beta_{6} S C Z O_{i} \\
& \quad+\beta_{7} S C R O_{i}+\beta_{8} S C W D_{i}+\beta_{9} \ln D O C H_{i}+\beta_{10} \ln D O C H^{2}{ }_{i}+\beta_{11} R E S D_{i}+\beta_{12} H T H_{i} \\
& \quad+\beta_{13} P C P L_{i}+\beta_{14} P U S E_{i}+\beta_{15} A A C T_{i}+\beta_{16} I N T C_{i}+\gamma_{1} P K B_{i j}+\gamma_{2} N R E G_{i j}+\gamma_{3} E N_{i j} \\
& \quad+\gamma_{4} W_{i j}+\gamma_{5} U N R_{i j}+\gamma_{6} P K T_{-} T_{i j}+\gamma_{7} N R E G_{-} T_{i j}+\gamma_{8} E N_{-} T_{i j}+\gamma_{9} W_{-} T_{i j}+\gamma_{10} U N R_{-} T_{i j} \\
& \quad+\sum_{j=1}^{10} \mu_{i j}+\varepsilon_{i}
\end{aligned}
$$

gdzie:

$P_{i} \quad$ - prawdopodobieństwo, że $i$-ta osoba doświadczy wystąpienia problemu prawnego,

1- $P_{i}$ - prawdopodobieństwo, że $i$-ta osoba nie doświadczy wystąpienia problemu prawnego,

$\beta_{i} \quad$ - parametr stojący przy $i$-tej zmiennej opisującej osobnicze cechy socjoekonomiczne (poziom mikro),

$\gamma_{j} \quad$ - parametr stojący przy $j$-tej zmiennej kontekstowej (poziom mezo, czyli poziom powiatu),

$\mu_{i j} \quad$ - grupowa zmienna losowa,

$\varepsilon_{i j} \quad$ - składnik losowy.

Omówieniu wyników empirycznych szacunku parametrów strukturalnych hierarchicznego modelu logitowego, danego równaniem (3), poświęcono kolejny punkt artykułu.

\section{Wyniki i dyskusja}

Rezultaty regresji zawarte $\mathrm{w}$ tabeli 3 wskazują na statystyczną nieistotność zmiennych kontekstowych oraz wyraźny - w stosunku do klasycznego modelu logitowego ${ }^{21}$ - spadek istotności kilku zmiennych poziomu mikro. Wariantu tego nie można uznać zatem za użyteczny, co implikuje konieczność zastosowania strategii modelowania od ogółu do szczegółu.

W tabeli 4 przedstawiono wyniki oszacowań wariantu szczegółowego równania (3). Kluczowymi czynnikami zwiększającymi ryzyko doświadczenia problemu prawnego jest indywidualna postawa wobec prawa, aproksymowana

${ }^{21}$ W. Florczak, W. Grabowski, op. cit. 
zmienną $P U S E$, oraz stan cywilny wskazujący na ,życiowe przejścia” i samotność (rozwodnicy $(S C R O)$, osoby owdowiałe $(S C W D)$ ). Okazuje się zatem, że subiektywny stosunek wobec stosowania prawa jest trwałym czynnikiem wpływającym na indywidualną skłonność do interpretowania pojawiających się zdarzeń życiowych w kategoriach problemów prawnych, co sprawia, iż osoby o pryncypialnym stosunku wobec prawa częściej doświadczają takich problemów ${ }^{22}$. Wzrost ,indeksu roszczeniowości" (zmienna PUSE) o jednostkę skutkuje wzrostem ilorazu szans zaistnienia problemu prawnego o $62 \%(\exp (0,48)-1) * 100)$.

Osoby rozwiedzione i owdowiałe wyraźnie częściej niż inni doświadczają problemów prawnych (ilorazy szans wystapienia problemu u takich osób wynoszą odpowiednio 4,4 $(\exp (1,42))$ i 3,75 $(\exp (1,32))$. Bezsprzecznie ważnymi okolicznościami wpływającymi na prawdopodobieństwo zaistnienia problemu prawnego są zmienne zastane, takie jak płeć i wiek. Kobiety częściej niż mężczyźni doświadczają problemów prawnych (iloraz szans równy 1,80), zaś wraz z wiekiem maleje podatność na jego doświadczanie.

TABELA 3: Rezultaty oszacowań parametrów strukturalnych hierarchicznego modelu logitowego (wzór 3)

\begin{tabular}{|l|c|c|c|c|c|}
\hline \multicolumn{1}{|c|}{ Zmienna } & $\begin{array}{c}\text { Oszacowanie } \\
\text { (odchylenie } \\
\text { standardowe) }\end{array}$ & $\begin{array}{c}\text { Graniczny } \\
\text { poziom } \\
\text { istotności }\end{array}$ & Zmienna & $\begin{array}{c}\text { Oszacowanie } \\
\text { (odchylenie } \\
\text { standardowe) }\end{array}$ & $\begin{array}{c}\text { Graniczny } \\
\text { poziom } \\
\text { istotności }\end{array}$ \\
\hline Wyraz wolny & $\begin{array}{c}3,07 \\
(8,63)\end{array}$ & 0,72 & PUSE & $\begin{array}{c}0,46 \\
(0,13)\end{array}$ & 0,00 \\
\hline FEM & $\begin{array}{c}0,48 \\
(0,26)\end{array}$ & 0,06 & $A A C T$ & $\begin{array}{c}0,54 \\
(0,32)\end{array}$ & 0,09 \\
\hline$A G E$ & $\begin{array}{c}0,13 \\
(0,05)\end{array}$ & 0,01 & $I N T C$ & $\begin{array}{c}0,65 \\
(0,34)\end{array}$ & 0,05 \\
\hline AGE & $\begin{array}{c}-0,001 \\
(0,0005)\end{array}$ & 0,02 & PKB & $\begin{array}{c}-0,02 \\
(0,02)\end{array}$ & 0,18 \\
\hline EDUP & $\begin{array}{c}0,60 \\
(0,52)\end{array}$ & 0,25 & NREG & $\begin{array}{c}-46,00 \\
(97,19)\end{array}$ & 0,64 \\
\hline EDUS & $\begin{array}{c}1,04 \\
(0,61)\end{array}$ & 0,09 & $E N$ & $\begin{array}{c}0,08 \\
(4,47)\end{array}$ & 0,99 \\
\hline SCZO & $\begin{array}{c}0,64 \\
(0,38)\end{array}$ & 0,09 & $W$ & $\begin{array}{c}0,0002 \\
(0,0007)\end{array}$ & 0,77 \\
\hline SCRO & $\begin{array}{c}1,97 \\
(0,57)\end{array}$ & 0,00 & UNR & $\begin{array}{c}5,95 \\
(6,69)\end{array}$ & 0,37 \\
\hline SCWD & $\begin{array}{c}1,96 \\
(0,60)\end{array}$ & 0,00 & PKB_T & $\begin{array}{c}0,01 \\
(0,04)\end{array}$ & 0,78 \\
\hline
\end{tabular}

22 J. Kurczewski, M. Fuszara, op. cit. 


\begin{tabular}{|c|c|c|c|c|c|}
\hline Zmienna & $\begin{array}{c}\text { Oszacowanie } \\
\text { (odchylenie } \\
\text { standardowe) }\end{array}$ & $\begin{array}{l}\text { Graniczny } \\
\text { poziom } \\
\text { istotności }\end{array}$ & Zmienna & $\begin{array}{c}\text { Oszacowanie } \\
\text { (odchylenie } \\
\text { standardowe) }\end{array}$ & $\begin{array}{l}\text { Graniczny } \\
\text { poziom } \\
\text { istotności } \\
\end{array}$ \\
\hline $\ln \mathrm{DOCH}$ & $\begin{array}{l}-2,65 \\
(2,36)\end{array}$ & 0,26 & $N R E G \_T$ & $\begin{array}{c}0,03 \\
(0,11) \\
\end{array}$ & 0,76 \\
\hline $\ln D O C H^{2}$ & $\begin{array}{c}0,18 \\
(0,17)\end{array}$ & 0,31 & $E N \_T$ & $\begin{array}{l}-0,29 \\
(0,17) \\
\end{array}$ & 0,09 \\
\hline RESD & $\begin{array}{c}-0,98 \\
(0,57)\end{array}$ & 0,08 & $W_{-} T$ & $\begin{array}{l}-0,13 \\
(0,24)\end{array}$ & 0,59 \\
\hline HTH & $\begin{array}{c}0,32 \\
(0,28)\end{array}$ & 0,25 & $U N R \_T$ & $\begin{array}{l}-0,01 \\
(0,05)\end{array}$ & 0,91 \\
\hline$P C P L$ & $\begin{array}{l}-0,27 \\
(0,27)\end{array}$ & 0,32 & $\begin{array}{l}\text { Wariancja } \\
\text { efektów } \\
\text { stałych } \\
=1,65\end{array}$ & \multicolumn{2}{|c|}{$\begin{array}{l}\text { Testowanie hipotezy o równości } \\
\text { parametrów w „,klasycznym” } \\
\text { i hierarchicznym modelu } \\
\text { logitowym Chi-kwadrat }=38,64 \\
\text { GPI }=0,000\end{array}$} \\
\hline
\end{tabular}

Źr ódło: obliczenia własne.

TABELA 4: Rezultaty oszacowań parametrów strukturalnych wariantu szczegółowego dla hierarchicznego modelu logitowego danego wzorem (3)

\begin{tabular}{|c|c|c|c|c|c|}
\hline Zmienna & $\begin{array}{c}\text { Oszacowanie } \\
\text { (odchylenie } \\
\text { standardowe) }\end{array}$ & $\begin{array}{l}\text { Graniczny } \\
\text { poziom } \\
\text { istotności }\end{array}$ & Zmienna & $\begin{array}{c}\text { Oszacowanie } \\
\text { (odchylenie } \\
\text { standardowe) }\end{array}$ & $\begin{array}{l}\text { Graniczny } \\
\text { poziom } \\
\text { istotności }\end{array}$ \\
\hline Wyraz wolny & $\begin{array}{l}-5,70 \\
(1,25)\end{array}$ & 0,00 & RESD & $\begin{array}{l}-0,96 \\
(0,45)\end{array}$ & 0,03 \\
\hline FEM & $\begin{array}{c}0,59 \\
(0,25)\end{array}$ & 0,02 & PUSE & $\begin{array}{c}0,48 \\
(0,13)\end{array}$ & 0,00 \\
\hline$A G E$ & $\begin{array}{c}0,16 \\
(0,05)\end{array}$ & 0,00 & $A A C T$ & $\begin{array}{c}0,63 \\
(0,31)\end{array}$ & 0,04 \\
\hline$A G E^{2}$ & $\begin{array}{c}-0,002 \\
(0,0005)\end{array}$ & 0,00 & INTC & $\begin{array}{c}0,66 \\
(0,32)\end{array}$ & 0,04 \\
\hline SCRO & $\begin{array}{c}1,48 \\
(0,46)\end{array}$ & 0,00 & $P K B$ & $\begin{array}{l}-0,02 \\
(0,01)\end{array}$ & 0,06 \\
\hline$S C W D$ & $\begin{array}{c}1,32 \\
(0,48)\end{array}$ & 0,01 & NREG & $\begin{array}{l}-0,25 \\
(0,14)\end{array}$ & 0,07 \\
\hline \multicolumn{3}{|c|}{ Wariancja efektów stałych $=1,80$} & \multicolumn{3}{|c|}{$\begin{array}{c}\text { Testowanie hipotezy o równości parametrów } \\
\text { w „,klasycznym” i hierarchicznym modelu } \\
\text { logitowym Chi-kwadrat }=56,41 \\
\text { GPI }=0,000\end{array}$} \\
\hline
\end{tabular}

Źr ódło: obliczenia własne.

Ostatnią grupę zmiennych socjoekonomicznych stanowią te, które opisują aktywność społeczną respondentów. Okazuje się, że w świetle wyników niniejszego badania czynny udział w życiu społecznym uznać należy za stymulantę 
pojawienia się problemu prawnego (ilorazy szans dla zmiennych $A A C T$ i INTC w obydwu przypadkach bliskie 2). Trudno jednak wskazać na behawioralny mechanizm takiego związku. Być może pasem transmisyjnym jest możliwość szerszego korzystania z nieformalnej pomocy innych osób w procesie identyfikowania doświadczanego problemu życiowego jako prawnego albo działanie w imieniu innych, czyli przedstawianie problemów innych osób, jako własnych.

Spośród rozważanych kontekstowych zmiennych mezoekonomicznych dwie okazały się statystycznie istotnymi destymulantami wystapienia problemu prawnego: PKB per capita oraz liczba mieszkańców przypadających na jeden zarejestrowany podmiot gospodarczy NREG. Wzrost PKB per capita o $1 \mathrm{zł} \mathrm{w}$ regionie prowadzi do spadku indywidualnego prawdopodobieństwa zaistnienia problemu o ok. $\left.2 \%(\exp (-0,02)-1)^{*} 100\right)$, zaś wzrost liczby mieszkańców na jeden podmiot gospodarczy w regionie o jedną osobę skutkuje spadkiem indywidualnego prawdopodobieństwa wystąpienia problemu aż od $\left.22 \%(\exp (-0,25)-1)^{*} 100\right)$.

Okazuje się zatem, że uwarunkowania mezoekonomiczne wpływają na regionalne zróżnicowanie częstotliwości występowania problemów prawnych. Oprócz kontekstowych uwarunkowań ekonomicznych na zróżnicowanie to wpływać muszą również inne czynniki kontekstowe, o czym świadczy duża zmienność oszacowań losowych efektów grupowych ${ }^{23}$.

\section{Uwagi końcowe}

Przedstawione $\mathrm{w}$ artykule badanie jest pierwszym zastosowaniem hierarchicznego modelu logitowego do kwantyfikacji wpływu indywidualnych cech socjoekonomicznych oraz uwarunkowań mezoekonomicznych na prawdopodobieństwo doświadczenia przez respondentów problemu prawnego. Zastosowanie strategii modelowania od ogółu do szczegółu dla dwóch wariantów ogólnych modelu pokazało, że w ich wariantach szczegółowych występują głównie zmienne mikroekonomiczne, ale mezoekonomiczne uwarunkowania regionalne także oddziałuja na prawdopodobieństwo pojawienia się problemu prawnego.

Wnioski płynące $\mathrm{z}$ badania mogą być użyteczne w przypadku prób ustanowienia systemu ubezpieczeń od wystapienia problemu prawnego, w którym ubezpieczyciel, oprócz uwzględnienia cech socjoekonomicznych ubezpieczającego, brałby pod uwagę miejsce jego zamieszkania. Wydaje się jednak, że w kontekście

23 Szczegółowe rezultaty badania dostępne na żądanie. Najogólniej przyczyny zróżnicowania spowodowane są zastanymi uwarunkowaniami historyczno-kulturowymi. 
rozważań nad alokacją środków publicznych na funkcjonowanie obecnego systemu nieodpłatnej pomocy prawnej uzyskane rezultaty nie są dostatecznie precyzyjne, aby sugerować inny przydział środków niż według kryterium ludnościowego ${ }^{24}$.

\section{Bibliografia}

Barro Robert, Inequality and Growth in a Panel of Countries, Journal of Economic Growth 2000/5.

Bartkowski Jerzy, Tradycja i polityka. Wpływ tradycji kulturowych polskich regionów na wspólczesne zachowania spoleczne i polityczne, Wydawnictwo Akademickie „Żak”, Warszawa 2003.

Biernacka Maria, Wsie drobnoszlacheckie na Mazowszu i Podlasiu, Wydawnictwo „Ossolineum", Wrocław 1966.

Breslow Norman, Clayton David G., Approximate inference in generalised linear mixed models, Journal of the American Statistical Association 1993/88.

Burdziej Stanisław, Dudkiewicz Marek, Korzystający i niekorzystajacy z poradnictwa prawnego i obywatelskiego, ISP, Warszawa 2013, http://isp.org.pl/uploads/filemanager/pliki/poradnictwo/RaportISPBeneficjencifinal16.04.13.pdf

Cameron Colin, Trivedi Pravin, Microeconometrics Using Stata, Stata Press, College Station, Texas 2009.

Chang Jih, Ram Rati, Level of Development, Rate of Economic Growth, and Income Inequality, Economic Development and Cultural Change 2000/48.

Coumarelos Christine, Wei Zhigang, Zhou Albert, Justice Made to Measure. NSW Legal Survey in Disadvantaged Areas, Law and Justice Foundation 2006, http://www.lawfoundation. net.au/report/survey2006

Curran Liz, Ensuring Justice and Enhancing Human Rights: A Report on Improving Legal Aid Service Delivery to Reach Vulnerable and Disadvantages People, La Trobe University and the Victoria Law Foundation 2007, https://papers.ssrn.com/sol3/papers.cfm?abstract $\mathrm{id}=2395075$

Currie Ab, A National Survey of the Civil Justice Problems of Low-and Moderate-income Canadians: Incidence and Patterns, International Journal of Legal Profession 2006/13.

Florczak Waldemar, Ile może kosztować reforma systemu pomocy prawno-obywatelskiej w Polsce, Studia Prawno-Ekonomiczne 2015/95.

Florczak Waldemar, Szacunki kosztów systemu pomocy prawno-obywatelskiej w Polsce, Wiadomości Statystyczne 2017/1.

Florczak Waldemar, Grabowski Wojciech, Co wptywa na wielkość popytu na porady prawne? Analiza logitowa z wykorzystaniem metody klasycznego uśredniania międzymodelowego, Przegląd Statystyczny 2017, przyjęto do druku.

Goldstein Harvey, Multilevel mixed linear model analysis using iterative generalised least squares, Biometrika 1986/73.

24 W. Florczak, Ile może kosztować reforma systemu pomocy prawno-obywatelskiej w Polsce, Studia Prawno-Ekonomiczne 2015/95; W. Florczak, Szacunki kosztów systemu pomocy prawno-obywatelskiej w Polsce, Wiadomości Statystyczne 2017/1. 
Goldstein Harvey, Restricted unbiased iterative generalised least squares estimation, Biometrika 1989/76.

Goldstein Harvey, Rasbash Jon, Improved approximations for multilevel models with binary responses, Journal of the Royal Statistical Society, Series A 1996/159.

Gramatikov Martin, Multiple Justiciable Problems in Bulgaria, Tilburg University Legal Studies Working Paper 2008/16, https://papers.ssrn.com/sol3/papers.cfm?abstract id=1308604

Gruszczyński Marek, Mikroekonometria. Modele i metody analizy danych indywidualnych, Oficyna Wolters Kluwer business, Warszawa 2010.

Hunter De Simone, Women, Legal Aid and Social Inclusion, Australian Journal of Social Issues 2009/44.

Jasiewicz Zbigniew, Rodzina wiejska na Ziemi Lubuskiej, PWN, Warszawa 1997.

Kritzer Herbert, Examining the Real Demand for Legal Services, Fordham Urban Law Journal 2009/37.

Kritzer Herbert, To Lawer or Not to Lawyer: Is that the Question?, Journal of Empirical Legal Studies 2008/5.

Kritzer Herbert, Bogart Bill, Vidmar Neil, Context, Context, Context: A Cross-problem, CrossCultural Comparison of Compensation Seeking Behaviour, Paper Prepared for Law and Society, Amsterdam 1991, http://users.polisci.wisc.edu/kritzer/research/propensity/context.pdf

Kuk Antony, Asymptotically unbiased estimation in generalised linear models with random effects, Journal of the Royal Statistical Society, Series B 1995/57.

Kurczewski Jacek, Fuszara Małgorzata, Polskie spory i sądy, Ośrodek Badań Społecznych ISNS, Uniwersytet Warszawski, Warszawa 2004.

Legal Service Corporation, Legal Needs and Civil Justice, A survey of Americans. Major Finding, from Comprehensive Legal Needs Study, 1994, http://www.americanbar.org/content/ dam/aba/administrative/legal_aid_indigent_defendants/downloads/legalneedstudy.authcheckdam.pdf

Lin Xihong, Breslow Norman, Bias correction in generalised linear mixed models with multiple components of dispersion, Journal of the American Statistical Association 1996/91.

McCulloch Charles, Maximum likelihood algorithms for generalised linear mixed models, Journal of the American Statistical Association 1997/92.

Murayama Masayuki, Experiences of Problems and Disputing Behaviour in Japan, Meiji Law Journal 2007/14.

Ng Edmond, Carpenter James, Goldstein Harvey, Rasbash Jon, Estimation in generalised linear mixed models with binary outcomes by simulated maximum likelihood, Statistical Modelling 2006/6.

Pleasence Pascoe, Balmer Nigel, Reimers Stian, What Really Drives Advice Seeking Behaviour? Looking Beyond the Subject of Legal Disputes, Onati Socio-Legal Series 2011/1.

Pleasence Pascoe, Buck Alexy, Balmer Nigel, O’Grady Aoife, Genn Hazel, Smith Marisol, Causes of Action: Civil Law and Social Justice. The Final Report of the First LSRC Survey of Justiciable Problems 2014, http://webarchive.nationalarchives.gov.uk/20100210214359/ http:/lsrc.org.uk/publications/Causes\%20of\%20Action.pdf

Preisert Arkadiusz, Schimanek Tomasz, Waszak Marcin, Winiarska Agata, Poradnictwo prawne i obywatelskie w Polsce. Stan obecny i wizje przyszłości, Instytut Spraw Publicznych, Warszawa 2013, http://www,isp,org,pl/uploads/pdf/443334703,pdf

Raudenbush Stephen, Yang Meng-Li, Yosef Matheos, Maximum likelihood for generalized linear models with nested random effects via high-order, multivariate Laplace approximation, Journal of Computational and Graphical Statistics 2000/9. 
Rodríguez German, Goldman Noreen, An assessment of estimation procedures for multilevel models with binary responses, Journal of the Royal Statistical Society, Series A 1995/158.

Winczorek Jan, Przeglad literatury na temat dostępności i korzystania z pomocy prawnej, INPRIS 2015, http://www,inpris.pl/fileadmin/user_upload/documents/pomoc_prawna/ Przeg1\%C3\%84\%E2\%80\%A6d_literatury_na_temat_dost $\%$ C3\%84\%E2\%84\%A2pno$\% \mathrm{C} 4 \% \mathrm{~B} 9 \% \mathrm{E} 2 \% 80 \% \mathrm{BAci}$ i_korzystania_z_pomocy_prawnej,pdf

Zarycki Tomasz, The electoral geography of Poland: Between stable spatial structures and their changing interpretations, Erdkunde 2015/69.

Waldemar FLORCZAK

Wojciech GRABOWSKI

\title{
DEMAND FOR LEGAL AID AS A FUNCTION OF INDIVIDUAL AND CONTEXTUAL FACTORS. ECONOMETRIC ANALYSIS BY MEANS OF A HIERARCHICAL LOGIT MODEL
}

\author{
( Sum mary)
}

The aim of this paper to quantify micro- and meso-level risk factors affecting individual demand for legal aid in Poland. On the basis of a literature survey and information taken from regional databases a set of relevant explanatory variables has been established, whose structural parameters were estimated by means of a hierarchical logit model. The regressors contained both objective and subjective micro-level information - such as income, age, education, gender, marital status, place of residence, personal attitude towards law, knowledge of law, social capital, and social activity - as well as meso-level information from demographic and economic areas. It follows from the results obtained on a representative sample of adult Poles that the risk factors belong mainly to the microlevel group, whereas contextual factors are of minor importance.

Keywords: hierarchical logit model; justiciable problems; socioeconomic factors; contextual factors 